\title{
Poor Man's Patriarchy: Gender Roles and Global Crises
}

\section{Alexandra Kelbert and Naomi Hossain}

\begin{abstract}
This article argues that rapid recent global economic shocks have revealed a poor man's patriarchy - a washed-out version of ancient male privileges, but yoked to responsibilities poor men can rarely meet. At the same time, norms that helped keep women at home in unpaid care roles have weakened and paid work is an ambition for more and more. Drawing on original research into experiences of food price volatility in ten developing countries in 2012, this article argues that in this destabilising of old gender roles, there may be some emancipatory potential. Present conditions of poor man's patriarchy suggest some scope for cross-gender coalitions with progressive, redistributive political agendas.
\end{abstract}

\section{Introduction}

This article takes a selective look at some of the prospects for emancipatory feminism within the context of global food price volatility. The focus is on showing how recent trends in the global economy are playing out in local markets and patterns of work and everyday life, and the implications for men, masculinity and everyday patterns of patriarchy. Evidence gathered as part of the ongoing Life in a Time of Food Price Volatility study $^{1}$ suggests that the majority of men - men on low and precarious incomes - at present enjoy the relatively limited privileges of a patriarchal system, or at least considerably fewer such privileges than they relatively recently believed they held. Further, while the privileges seem somewhat fewer, the burdens appear greater. As such, it appears that theirs is a 'poor man's patriarchy' in two ways. First, a set of norms about male rights and responsibilities sets standards for the lives of men living in or near poverty. Second, both the rights and responsibilities are weakly adhered to in a watered down version of masculinity that revolves around the idea of the male breadwinner or provider.

If these everyday patterns of patriarchy are holding true beyond the 23 communities in which this research was conducted, and sustained over time, then the question emerges: what do poor men have to gain from patriarchy as we have known it? Can the impoverishment of everyday patriarchy provide the spur for cross-gender coalitions for more emancipatory social justice?

The article first sets out some of the conceptual issues with which it grapples. Nancy Fraser's work on feminism and the present global crisis is particularly fruitful in thinking about these issues, in particular her recent reflections on Polanyi's take on the political response to earlier capitalist crises (Fraser 2012, 2013). Specifically, her focus on analysing the historical moment in global economic development, her insistence on the need for a properly global analysis, given economic and other integrations, and her recognition of the ambivalences involved in a feminist emancipatory project in this time, help make sense of the directions of poor man's patriarchy. The article refers to some of the empirical findings we believe provide evidence of this impoverished form of patriarchy. Some of these have been presented elsewhere, and so more of a summary than a detailed analysis is provided of the findings on care. The article concludes with a summary, and thoughts about the directions men's political mobilisation might and has taken in the recent past.

For the sake of argument, and in order to later introduce what we see as a new phenomenon of 'poor man's patriarchy', we briefly outline some of the key characteristics of patriarchy as we understand it. Patriarchy originates from the 
Greek word for 'the rule of fathers' and was, until the early twentieth century, widely used to refer to the rule of men in society (in both public and private spheres).

Feminist theorists have expanded the definition of patriarchy and the patriarchal society to describe a systemic bias against women. Today, debates around patriarchy are central to discussions on structures of constraint such as gender inequality, discussions of heteronormativity and hegemonic masculinities. Intersecting forms of oppression in relation to forms of difference other than gender sexual orientation, class and race - are also now considered intrinsic to wider patriarchal structures.

\subsection{The Life in a Time of Food Price Volatility project}

The primary research on which this article draws is from the Life in a Time of Food Price Volatility project. This is a four-year initiative (2012-15) to study the social impacts of and responses to volatile and rising food prices in poor communities in ten developing countries. ${ }^{2}$ The relevance to norms about the roles of men as breadwinners and of women as caregivers is that rapid food price rises and spikes disrupt patterns of everyday consumption: both provision and care can become more difficult if cash and time are squeezed as people have to work harder and spend more to maintain their standards of living.

To explore these and related issues, teams of researchers conducted research on everyday life experiences of food price volatility in mid to late 2012, working in 23 rural, urban and peri-urban communities in ten countries - Bolivia and Guatemala in Latin America, Burkina Faso, Ethiopia, Kenya and Zambia in sub-Saharan Africa, and Bangladesh, Indonesia, Pakistan and Vietnam in South and Southeast Asia. The research was the first round ${ }^{3}$ of a four-year project centred on understanding how family life patterns and social relations are affected by changes in food prices, in light of the extended period of volatility in global and national food markets, and ongoing rapid inflation in the cost of living. A detailed account of the methodologies used and analysis undertaken is available in Hossain et al. (2013). In order to collect the data, focus group discussions with different occupational and social groups, household case studies and key informant interviews were conducted in each community. Common questions were asked but the tools and instruments were developed to fit each country and research context. The qualitative data were translated into English, and coded using qualitative analysis software. National and local data on food prices, food security, poverty, agriculture and economic development were used to help situate the findings. In all ten countries, many food prices had increased in the previous year, but staples had been stable or even declined in communities where people ate mainly rice (mostly Asia). Even though most groups said their wages had increased, many did not feel they had increased enough to out-pace inflation, so they were worse off than in the recent past.

The long-term drivers of prices, including increasing agriculture-energy and agriculture-finance linkages, climate change, and variability, mean that the threat of future episodes of price volatility continues to be real, and there is little chance of global prices returning to their pre-2007 levels. As such, findings from the first year of research point to changing work patterns, diets and the myriad of ways respondents explained they adapted in order to cope with uncertainty. In this article we focus on findings about views on men's changing masculinities and roles as breadwinners, and on the provision of unpaid care.

\section{Global crises and the political response}

A key theme emerging from the study is the changes in men's roles as providers in a time of rapid and generally sustained food price and other cost of living rises worldwide. These rises are closely linked to both financialisation, or the rise of financial 'services' as an important element of the global economy, and to the crisis of the environment, both its degradation and the spectre of climate change, which was behind the bio-fuelled food price spike of 2008. This has meant a shift in global food price patterns, from decades of relatively low and stable food prices, to fast and often unpredictable rises in the basic costs of everyday life post-2008 (Gilbert and Morgan 2010; Naylor and Falcon 2010).

Not surprisingly, higher food prices make providing for families both tough and uncertain, particularly in the period before wages adjust to higher prices. However, wages do appear to have adjusted to higher prices, even though prices continue to rise and some occupational groups find it harder than others to bid up their wages or to cope in the interim period. These changes have 
not been confined to any particular part of the world (although some countries' exposure to global food, oil and other import markets has left them more vulnerable than others). Everywhere and everyone has seen food prices rise, and although there are winners and losers from higher food prices, there is a sense that everyone has been spending proportionately more on basic household costs than before the food price spike of 2008.

It is not only men's roles as breadwinners ${ }^{4}$ that have been directly hit by price rises: women's roles as unpaid providers of care - feeding families, looking after the young, the old and the sick, cleaning, grooming, socialising - also appear to be changing rapidly. This work is consistently seen as the role of women and to some extent girls in most societies, although there may be particular cultural variants in, for instance, the extent to which men do childcare or food marketing. These changes occur because pressure on household food budgets not only means more pressure to stretch resources to make ends meet and to conserve or produce more at home, usually involving more time and effort, but it also often means more pressure on women to contribute by earning cash incomes. The double or triple burden of the careproviding, food-growing and cash-earning women will mean the quality of care being provided must suffer, and with it, the quality of life and human wellbeing. The idea that the resources for social reproduction or care are being depleted rapidly in the current phase of capitalism is reasonably well established (Rai et al. 2010). Our analysis aims to contribute to this debate with evidence about the specific effects on provisioning for family life and unpaid care work when food prices and other basic costs of living rise rapidly and over a sustained period.

What do these global crises, and in particular the acceleration of commodification that has come about with the rapid rise in the cost of living worldwide, mean for the politics of gender equality? ${ }^{5}$ Present economic patterns, with their pressure on the household food budget and pressure to earn cash incomes, can easily be seen as unmitigated bads for the feminist project.

Global economic integration entails more contagion than it does scope for solidaristic action by the groups it affects. However, it would be difficult to argue that the past decade, with all its economic, financial, commodity and political crises, has offered no scope for a feminist project, or that the global crises have been uncomplicated in their effects on communities and emancipatory struggles. Economic crisis was coupled with economic growth, and rapid declines in income poverty in recent years, thus pointing to (some) emancipatory potential stemming from neoliberal economic development, for people who were previously living in situations of great material precariousness. Indeed, some of the growth has made its way into the pockets of the poor, at least in the global South, via their labour, with many being quite rapidly drawn into - or thrown onto - the market. People's labour and lives have become part of the market, with all the pressures that come from working under industrial discipline and/or having to earn a daily cash income, without being able to rely on the common resources of the community or the state.

As such, the integration into markets appears to contain elements of emancipatory potential. In a context where the market is all and everything and everyone's labour is bought and sold on the market, the question arises of whether it is better to be integrated than not. This proves particularly problematic for those of us who see the damage that late-phase capitalist commodification causes to communities, environments and people.

Nancy Fraser's view is that the politics of the response to the global crises is an awkward clash of pro-market, protective and emancipatory drives (Fraser 2013). She identifies three strands to the contemporary 'triple movement' that comprises the political response to the present global crisis:

\section{A push from the right to further commodification ('marketisation');}

2 A contra movement towards protection of society and environment against the spread of the market ('social protection'), respectively the movement and counter-movement familiar from Polanyi's 'Great Transformation'. She also identifies a more recent complicating thrust in the form of:

\section{An emancipatory movement against} domination (by patriarchy, ethnic, religious or sexual majorities, etc.).

Emancipatory movements - including feminism complicate the previously simple left-right binary 
of world politics. Each of the three can be a bedfellow for the other, under certain conditions:

Marketisation [or commodification] may indeed have the negative effects Polanyi stressed. But as Marx appreciated, it can also beget positive effects, to the extent that the protections it disintegrates are oppressive as, for example, when markets in consumer goods are introduced into bureaucratically administered command economies, or when labour markets are opened to those who have been involuntarily excluded from them (Fraser 2013: 129).

This is particularly relevant to women, and even more so to women who have traditionally been excluded from paid work. As Naila Kabeer has argued against those who see women's paid work as oppressive, for Bangladeshi women to be allowed to work in factories earning regular incomes alongside men instead of being secreted in village homes producing paddy and people marks a dramatic gain in their power (Kabeer 2002).

Thus some neoliberal policies have been a friend to feminism, particularly by pushing open the doors to labour markets previously closed to women. However, these same policies are implicated in depleting the resources for social reproduction or care (Rai et al. 2010). Elsewhere Fraser has noted that neoliberal policies that draw women into waged work have been critical to the 'romance of female advancement and gender justice', a romance in the sense of an enchantment, or a lie (Fraser 2012: 110-11).

Returning to the politics of the crisis, Fraser also adds that:

Nor, importantly, is emancipation immune from ambivalence, as it produces not only liberation but also strains in the fabric of existing solidarities. Even as it overcomes domination, emancipation may help dissolve the solidary ethical basis of social protection, thereby clearing a path for marketization (Fraser 2013: 129).

The 'dissolution of the solidary ethical basis of social protection' is precisely what we are seeing in the challenges to male authority and masculine identities as providers. Whereas men - specifically, husbands and fathers - were once the main source of protection (and domination), in several contexts, this role has been under threat for some time, and in others is newly so. This process of change in gender roles and relations under processes of economic restructuring is familiar from Helen Safa's work on the Caribbean region (Safa 1995). In contexts where the food crisis has not meant a significant squeeze on incomes and livelihoods, perceptions and norms about the roles of men as providers appear undisturbed, at least at present. A more consistent finding across the research contexts was the pressures women face in their roles in unpaid care or domestic and family work, and corresponding pressures to contribute cash to the household economy. The following section looks at perceptions of men's changing roles and capacities for providing, and views on how care is changing.

\section{Gendered roles in inflationary times}

\subsection{Men's roles as breadwinners}

People were asked whether their relationships, domestic and wider social networks, were being affected by cost of living rises. In contexts where food price rises were leading to considerable hardship - all communities and people who were living in or vulnerable to poverty - the answer was that it was having significant adverse impacts, particularly on marital relations as men's roles as providers were challenged (Hossain et al. 2013).

Two related ideas stood out as predominant: that failures to provide adequately for families had become a more important source of domestic strife, and that masculine identities were being adversely affected by this. In Dhaka, Bangladesh, Mrs H, a 33-year-old caretaker of a daycare centre said of her 35-year-old occasionally employed husband:

We are passing the month of holy Ramadan [fasting]. So the children want to eat iftar but where is the money? Their father bought a half $\mathrm{kg}$ of dates before Ramadan. Every day we eat one... date, one glass of sherbet and four glasses of water at iftar to break our fast and to finish our iftar we eat rice that is brought from the daycare centre. But the children do not want to take iftar in such a way, so they start to shout/cry right before the time of iftar. Moreover, family unrest starts due to lack of... earnings, there are quarrels between husband and wife, the rate of beating children increases and these are the scenario of slums I often see. Sometimes we face this situation too. 
As with $\mathrm{Mrs} \mathrm{H}$, there was a common sense idea that not having enough to feed the family properly would inevitably cause problems. Cases of divorce, wives taking off to natal homes, or of men leaving, ostensibly migrating, were mentioned in many communities, but arguments and physical violence were more commonly mentioned. In tightly packed slum neighbourhoods, people hear a great deal of their neighbours' business, and know - or think they know - the causes of their conflicts. Failures by men to provide appeared to be most contentious where they were using drink or gambling to cope, or when they were not seen to be working hard enough to provide. Where men were seen to be trying hard to provide, women could be more forgiving.

The ideal of cooperation between marriage partners with specific reference to the difficulties men face in providing for their families was also mentioned in a number of different contexts. In Ethiopia and Kenya, people spoke of domestic harmony and respect as at the heart of family wellbeing, and there, as in Bangladesh, women and men both gave examples of how they had tried to resolve problems caused by being unable to feed the family. A 29-year-old grain-seller in western Oromia in Ethiopia gave an idealised account of how wellbeing was linked to a man's ability to provide:

\section{Being able to live well in this community is when someone is able to support himself and his family. Living well is when the income and expenditure gets balanced and beyond that when he can make savings and assist his family... family life is going to be said to be well when they listen to each other in the family. When a family is able to nurture its members, it is good for the family and the country.}

Several women gave moving testimony of the sympathy they felt for their husbands when they were unable to meet their needs, despite their best efforts. Mrs K, a 25-year-old mother of four in Gulshan-e-Iqbal in Karachi told this story of her 28-year-old rickshaw-puller husband:

One day he had to remain hungry and my heart ached; he said it was okay. I was crying; he was a poor man and where should one go. One day I cried a lot: he asked for food at 1.30am and I told him there wasn't any food. He hadn't given me money in the morning and when I checked his pockets I found nothing except the 200 rupees for the rickshaw instalment. Fifty to sixty rupees I had used for the children's breakfast and to give them for school.

Unlike Mrs K, in several households, we were told, women had spent money needed to repay debts or make instalments in order to keep food on the table.

Older men in Lango Baya, in coastal Kenya, asserted the importance of cooperating with their wives. A village elder asked 'if you will not cooperate with your wife who else will you cooperate with?', while another stated: 'having peace in your house is very important. When you and your wife have peace then when you agree on something, it is as so. But when peace is lacking even eating becomes a problem.' These views contrasted with those of the younger generation and people in Mukuru in Nairobi, for whom marital cooperation seemed fragile. A group of young women, ranging from teens to late twenties, in Mukuru noted the fear in their area that husbands would be 'snatched' by richer older women. Mrs W described how her husband had gone off with an older woman 'just because she had more money than me... I don't know what he saw in her but am sure it is the money and the life where you sit and everything comes'. The reversal of more conventional patriarchal gendered transactions around sex and material benefits seems to reflect the extreme nature of the deprivation being faced in Kenya - drought and the food security crisis had been ongoing for seven years by 2012. Yet it also seems to reflect a deeper-seated radical destabilisation of older gender norms within some marginalised populations, such as urban slum-dwellers (on how masculinity has been affected by economic hardship and social change in Kenya, see Silberschmidt 1992, 2001).

The idea that providing for families was a core aspect of masculinity seemed to be taken for granted and was rarely spelt out. Outsiders sometimes saw the problems caused by damaged masculine psyches most clearly. The coordinator of a Lusaka NGO that cares for domestic violence survivors said:

Stress can also cause violence, for example due to inadequate finances. We receive more cases with families in poverty than those that are not due to increased stress and conflicts about finances and other aspects. Poverty questions the man about his 
manhoodness and if the woman touches on that, it may result in violence. Poverty also makes the victim powerless to take action.

In Nairobi, a community health worker described how 'not very energetic' men would resort to drinking:

\section{They do this to forget the burden of providing and they will demand food once they get home and beat their wives as well. Most women have run from their houses because of such behaviours.}

A doctor in Karachi gave a parallel account from his professional capacity:

\section{The rising prices impact women the most. We had a certain case where a Pathan woman came to get her blood pressure checked. When we inquired about her history, she told us that her husband had beaten her and so she felt pain in the right side of her body. She further told us that she was beaten by her husband because she demanded him to fulfil their domestic expenses. This story is two to three years old. Obviously women remain the most vulnerable because they demand their husbands to meet domestic expenses. When I asked the woman whether her husband was a drug addict, she told me it was nothing like that; he just did not offer prayers or fulfil domestic needs and they had five to seven children. We observe numerous quarrels because of food shortages.}

The ideal that men should provide appeared particularly strong in the Pakistani communities in which we worked, to the extent that women often neither knew their husbands' wages nor the prices of goods. By contrast, in the more genderequitable communities in Bangladesh, women seemed to be both more empowered to argue with their husbands about food shortages, and several households featured a more cooperative approach to provision, suggesting a greater degree of gender equity over basic household provisioning. In a striking departure from age-old tradition, some men in the Bangladesh communities were said to be asking their wives to take over their roles in food marketing.

Apparently embarrassment about having to buy goods in tiny quantities, to haggle or to buy inferior goods, as well as the presumption that women are better at economising and making things stretch, was behind this decision. That this reverses ancient traditions of markets as male public spaces is a striking finding.
Inability to provide was mentioned as a reason to delay marriage in Ethiopia, Kenya, Bangladesh and even in relatively better-off Indonesia.

Twenty-four-year-old Mr W, a sometime actor or performer in Nairobi noted that:

\section{Some men like us fear marrying now because if I cannot feed myself how will I feed someone else? By my own I can decide not to eat today, and probably eat the following day, but if you are with someone else it is difficult to make such decisions.}

The idea that Mr W 'can decide not to eat today' highlights how small his sphere of action is. The larger point is the impacts on sexuality and sexual relations. In rural northwest Bangladesh, a village 'doctor' explained that his practice had been impacted by the food price situation, with manual workers complaining of inability to perform sexually due to insufficient nutritious food. He noted that his customers' wives' sexual expectations had been raised by watching TV, and that their husbands' failures to meet those were leading to marital breakdown and extramarital activity. The 'doctor' may have been unusually focused on this matter because he had himself experienced sexual problems as a result of debt-related worry, and his own wife was unhappy with him about this.

\subsection{Women's double shift}

A key finding from our research in 2012 was that women were doing more paid and cost-saving work, which meant that others were doing more of the essential work of care, particularly grandparents and older daughters. In some instances, too, unpaid care work was being left undone or, by people's own standards, done inadequately. Among the poorest countries, women in Burkina Faso were involved more in trading or working as domestic helpers, than in the recent past. In Addis Ababa in Ethiopia, women traders noted more interest among women to obtain micro-credit for small businesses, perhaps because women there noted that any jobs available to them (construction work, laundry) were very low paid. In Nairobi, more women were looking for laundry and similar work than in previous years, while more women (and men) were said to be going to bars to look for sex work when prices were high. In Lango Baya in Kenya, more women were taking up wage labour and burning charcoal for sale. 
In Lusaka in Zambia, women employed as teachers and nurses were moonlighting as traders to help manage rising household costs. In Guatemala, women had recently taken on work for additional incomes, specifically to feed their children. When women left the home to wash clothes or sell goods at the market, their young children were cared for by grandmothers or older sisters. Boys also learnt to do housework, and young women there said that work was based on age rather than on gender. In rural southern Bangladesh, a series of livelihood shocks had increased women's participation in paid work. Mr I, a 40-year-old jungle fisherman, explained how the need for women's incomes was changing older dynamics between the generations, and drawing on care from grandparents. In the rural northwest of the country Muslim women were said to be reluctant to work in the fields or on building sites, but more were running small shops, processing, and growing their own vegetables, or rearing poultry or goats.

In middle-income countries with less acute food security concerns, women were still found to be seeking paid work wherever possible. In Vietnam, the rising cost of living meant, more so than before, that only those women who considered themselves too elderly or ill and those with infants were not in paid work. In many cases, grandmothers were cooking and caring for their daughters' and their own families. In Bolivia, urban women felt the pressure to earn more money, and urban women traders concluded they had less time for their children, who were leaving their studies and not eating properly because there was nobody to cook for them. One embroiderer said she sometimes worked through the night to pay for food when her migrant husband had not sent her money on time. Other women looked for work as housecleaners or carers of elderly people. In Pakistan, despite limited availability of work and social restrictions on women's mobility, there were signs of demand for paid work among women. Poor urban women worked as maids and others sewed quilts for extremely low pay - typically PKR 200-300 (\$2.14-\$3.21) for a quilt stitched over a month. A key informant noted that since the 2010 floods, women from the Baloch and Sindhi communities had become street sweepers and waste recyclers. Rural respondents commented approvingly that educated young women were working in NGOs and private firms, earning good incomes.
This recent trend of increased participation of women in paid work as a result of price rises has had a clear impact on care work. Some women were working longer hours or combining activities. Several reported being 'exhausted' by the effort of reconciling work with domestic responsibilities, which was equally the case of several men who were working longer hours in order to provide for their families.

For many people, two groups were taking on more care responsibilities. The first and most widely mentioned were grandparents, or the older parents of adult children. Where families were extended or lived in comparatively close proximity, grandparents had become a more important source of childcare and provided other kinds of assistance, including cooking and housework. Grandparents appeared to be particularly important sources of childcare in Vietnam, where older people also extended such childcare services to members outside their families as a source of income. Even when households separated formally, a great deal of mutual support remained between adult children and their parents. However, this was not always a satisfactory arrangement for the grandparents, many of whom expressed that they would prefer to earn their own incomes or care for their own dependents.

The second group who were taking on care work was older daughters and, in a small number of cases, older sons, who were helping out at home more than in the past. In rural Ethiopia, one woman explained that in her efforts to feed her family she worked on the farm with her husband; however, this meant that her oldest daughter at home had to take over the housework, which was affecting her schoolwork.

There were also cases where no one had been able to shoulder the unpaid care tasks in substitution for the mother. In a focus group in Bolivia, some urban women traders concluded that they had less time for their children, who were leaving their studies and not eating properly because there was nobody to cook for them, due to the longer working hours. Such stories point to the impact of food price volatility on the distribution of unpaid care, but also to its quality.

\section{Conclusions}

Early findings from the first year of the Life in a Time of Food Price Volatility project suggest ways in 
which the apparently solid ground of economic power and privilege that underpins everyday patriarchy may be shifting with economic change. The period since 2008, with its highly contagious global economic, financial, environmental, commodity and political crises seems to have meant a particularly rapid series of changes. Reliance on markets, or commodification, has been sped up, in particular by the increasing share of spending on basic living costs, which cannot be postponed or prevented.

As people's relationships to markets have changed, so have their relationships with each other, and to state and community sources of social protection. Fraser's analysis of the triple movement as the response to neoliberal domination of global economic policymaking helps us make sense of these multiple directions of change, and of the response they engender, simultaneously. The destabilisation of men's roles as providers and the matching entrance of

\section{Notes}

1 Life in a Time of Food Price Volatility is a fouryear (2012-15) research project partnership between Oxfam GB and IDS and research partners in ten countries, funded by DFID and Irish Aid. The authors are very grateful to Oxfam GB and in particular to our research partners for permission to use these research findings. Particular thanks are due to the research participants who have given us their time to help us understand these issues, many of them since 2009. A full list of research partners and other outputs can be found at http://policy-practice.oxfam.org.uk/ourwork/food-livelihoods/food-price-volatilityresearch. Any errors of interpretation are those of the authors.

2 Squeezed, the report for Year 1 results can be found at http://policy-practice.oxfam.org.uk/ publications/squeezed-life-in-a-time-of-foodprice-volatility-year-1-results-292412.

3 In eight of the research sites, the 2012 fieldwork was actually the fourth research more women into paid work further depletes the resources for social reproduction, creating urgent concerns about the quality of care. Yet there is also emancipatory potential, most plainly for women, but also for poor men who have less invested in old school patriarchy than before (and indeed, than richer men). There is, perhaps, some basis for cross-gender solidarity in an emancipatory project that prioritises the protection of care or social reproduction without forcing women into the roles of unpaid, unacknowledged carers. To explore this further, we are now in the process of developing a research agenda to explore the political expressions of 'poor man's patriarchy', with a focus on the unruly political responses to food price spikes and austerity packages in recent economic crises. It is in these unruly political expressions to the present moment of global capitalism that we may see the emancipatory potential of rapid shifts in gender roles in these times of rapid economic change.

round, as the research started as a study of the social impacts of the food, fuel and financial crises in 2009. This previous study can be found at www.ids.ac.uk/files/dmfile/ AccountsofCrisisFINAL.pdf.

4 Here it should be stressed that for the sake of concision we refer to men's roles as breadwinner, when in fact we are aware that in many societies it is a common perception that men are the main breadwinners, despite large numbers of women being effectively in the position of the main earner, single mothers, or for various reasons bearing the major responsibility for food security and basic needs. For more on this see Safa (1995).

5 Analysis has recently emerged on these issues, but there is little micro-evidence so far about how gender relations and the prospects for gender equality have been shaped by the recent crises in global capitalism or global food crises. For an authoritative account of the gendered effects of the 2008 crisis, see Fukuda-Parr et al. (2013). 


\section{References}

Fraser, N. (2013) 'A Triple Movement? Parsing the Politics of Crisis after Polanyi', New Left Review 81: 119-32

Fraser, N. (2012) 'Feminism, Gapitalism, and the Cunning of History', New Left Review 56: 97-117

Fukuda-Parr, S.; Heintz, J. and Seguino, S. (2013) 'Critical Perspectives on Financial and Economic Crises: Heterodox Macroeconomics Meets Feminist Economics', Feminist Economics 19.3: 4-31

Gilbert, C.L. and Morgan, C.W. (2010) 'Food Price Volatility', Philosophical Transactions of the Royal Society B: Biological Sciences 365: 3023-34

Hossain, N.; King, R. and Kelbert, A. (2013) Squeezed: Life in a Time of Food Price Volatility, Year 1 Results, Oxfam Research Reports, Oxford: Oxfam GB

Kabeer, N. (2002) The Power to Choose: Bangladeshi Garment Workers in London and Dhaka, London: Verso
Naylor, R.L. and Falcon, W.P. (2010) 'Food Security in an Era of Economic Volatility', Population and Development Review 36.4: 693-723

Rai, S.; Hoskyns, C. and Thomas, D. (2010) Depletion and Social Reproduction, Centre for the Study of Globalisation and Regionalisation, Department of Politics and International Studies, Coventry: University of Warwick Safa, H. (1995) 'Economic Restructuring and Gender Subordination', Latin American Perspectives 22.2: 32-50

Silberschmidt, M. (2001) 'Disempowerment of Men in Rural and Urban East Africa: Implications for Male Identity and Sexual Behavior', World Development 29.4: 657-71

Silberschmidt, M. (1992) 'Have Men Become the Weaker Sex? Changing Life Situations in Kisii District, Kenya', The Journal of Modern African Studies 30.02: 237-53 